\title{
Aggregation of Phaeocystis during phytoplankton spring blooms in the southern North Sea
}

\author{
Ulf Riebesell *
}

\author{
Alfred Wegener Institute jor Polar and Marine Research, Postiach, D-27515 Bremerhaven, Germany
}

\begin{abstract}
The role of aggregation during the decline of 2 phytoplankton spring blooms dominated by the Prymnesiophycean Phaeocystis sp. was studied in the southern North Sea in 1989 and 1991 While marine snow aggregates were devoid of Phaeocystis in 1989, a large fraction of the Phaeocystis biomass was associated with aggregates 2 yr later This discrepancy corresponds to a significant difference in aggregate size between the 2 years studied, which is interpreted to be a consequence of different levels of turbulent mixing. Phaeocystis colonies remained freely suspended during 1989 when aggregates were small, and adhered loosely to the large aggregates observed forming during 1991. Overall, the aggregation potential of Phaeocystis was low in comparison to diatoms. Independent of the degree of aggregation, sedimentation was the dominant loss factor of Phaeocystis biomass from the upper layer. The significance of a low aggregation potential for the role of Phaeocystis in massive foam formation along the North Sea coast is discussed.
\end{abstract}

\section{INTRODUCTION}

Massive blooms of the colony-forming Prymnesiophycean Phaeocystis are a recurrent phenomenon in the coastal zones of the North Sea (Lancelot et al. 1987) and have been repeatedly reported form several other locations, including the Barents Sea Wassmann et al. 1990), the Greenland Sea (Baumann 1990, Smith et al. 1991), the Norwegian fjords (Eilertsen et al. 1981), the Weddell Sea (Buck \& Garrison 1983), the Bransfield Strait (Bodungen et al. 1986) and the Ross Sea (ElSayed et al. 1983, SooHoo et al. 1987). Despite the widespread occurrence of intense blooms of Phaeocystis and their potential importance for carbon cycling in the ocean, the fate of the biomass accumulated during such blooms is still unresolved (see review by Wassmann in press).

Considerable controversy exists over the role of grazing as a loss factor during the decline of Phaeocystis blooms. Whereas an inhibitory effect of Phaeocystis colonies on zooplankton predation has been suggested by several authors (e.g. Schnack et al. 1985, Verity \& Smayda 1989), others have reported predation of both

\footnotetext{
- Present address: Marine Science Institute, University of California, Santa Barbara, California 93100, USA
}

colonial and single-celled Phaeocystis by copepods and microzooplankton (e.g. Tande \& Båmstedt 1987. Weisse \& Scheffel-Möser 1990). While the rapid decline of Phaeocystis blooms was attributed to herbivorous grazing by Tande \& Båmstedt (1987) and Lutter et al. (1989), Hansen \& van Boekel (1991) estimated the loss due to grazing during a Phaeocystis bloom in the Marsdiep (The Netherlands) to be less than $1 \%$ of the phytoplankton standing stock per day.

Disintegration of Phaeocystis colonies and the release of small flagellated cells from the colonies during the decline of a bloom were observed by Veldhuis et al. (1986). Cell lysis after nutrient depletion was suggested to be the dominant loss factor during a Phaeocystis bloom in the Marsdiep (van Boekel et al. 1992). On the other hand, mass sedimentation following a Phaeocystis bloom in the Barents Sea was observed by Wassmann et al. (1990), who attributed the enhanced vertical flux at the end of the bloom to the formation of fast-sinking marine snow aggregates. Colonisation of senescent Phaeocystis colonies by phytoplankton and microheterotrophs and aggregation with detrital material was also reported by Rousseau et al. (in press). Despite this type of circumstantial evidence for aggregation of Phaeocystis colonies, there is as yet no direct evidence of the aggregation potential of this species. The objec- 
tive of this investigation was to characterize the aggregation behaviour of Phaeocystis in situ during the decline of 2 Phaeocystis blooms.

\section{MATERIAL AND METHODS}

Study locations and sampling procedures. Investigations were conducted in the German Bight, North Sea (Fig. 1), during 2 blooms of Phaeocystis cf. globosa in May 1989 and May 1991. In 1989, 4 stations along a W-E transect east of Helgoland Island were sampled on May 17 (Stn 1, $22 \mathrm{~m}$ water depth (wd); Stn 3, $14 \mathrm{~m}$ wd) and May 19 (Stn 2, $19 \mathrm{~m} \mathrm{wd;} \mathrm{Stn} \mathrm{4,}$ $11 \mathrm{~m}$ wd). In 1991, 3 stations in close proximity to Helgoland Island (Stn I to III, $16 \mathrm{~m}$ wd) were sampled on May 8 and 10.

At each station, seawater was collected in 101 Niskin bottles at 4 depths to determine chlorophyll $a$ and phytoplankton cell concentration and composition. Temperature and salinity profiles were taken with a WTW LF 191 conductivity meter. Aggregate size and abundance were determined from 36 exposures randomly taken at various depths throughout the water column with a NIKONOS-V underwater camera system (described in Riebesell 1991a). At the same depths, SCUBA divers hand-collected 10 to 20 individual aggregates, each in $1 \mathrm{ml}$ polypropylene syringes (method described in Riebesell 1991b). At each depth, aggregate-free water surrounding the aggregates was sampled in $50 \mathrm{ml}$ syringes

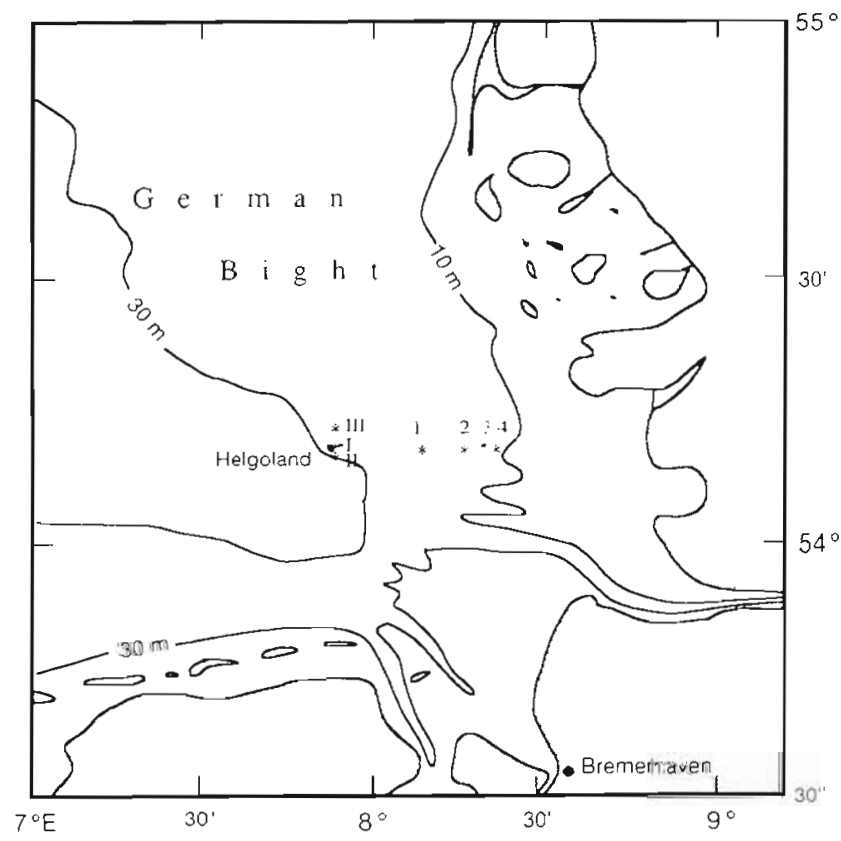

Fig. 1. Location of sites sampled in 1989 (Stns 1 to 4) and 1.991 (Stns I to III)
Phytoplankton cell concentration and composition in the surface water were monitored over the course of the spring blooms at a station 2.5 nautical miles west of Helgoland Island in 1989 (data taken from Riebesell 1991b), and at the Helgoland Roads Station in 1991 The latter is monitored daily by the staff of the Biologische Anstalt Helgoland (Radach et al. 1990) and its location corresponds to Stn I of this study.

Laboratory analyses. For the determination of chlorophyll a, $500 \mathrm{ml}$ of sample water were filtered onto $25 \mathrm{~mm}$ Whatman GF/C glass fiber filters. After extraction in $90 \%$ acetone (filters were homogenized with glass beads), the chlorophyll a concentration was measured using standard fluorometric methods (Parsons et al. 1984).

Phytoplankton cell number and composition, as well as fecal pellet abundance, were determined microscopically for individual aggregates, the aggregatefree surrounding water, and the bulk water samples collected with Niskin bottles. From each station and depth, $50 \mathrm{ml}$ of bulk and surrounding water and 3 to 6 individual aggregates preserved with formalin ( $2 \%$ final concentration) were analysed microscopically for phytoplankton composition and concentration and fecal pellet abundance. A minimum of 200 cells of the dominant species were counted in bulk and surrounding water samples. For Phaeocystis colonies with more than 100 to 200 cells, known fractions of the colonies were enumerated and extrapolated to yield cell numbers of the entire colonies. In aggregates, all phytoplankton cells and fecal pellets were counted.

To account for differences in cell volume between species, phytoplankton numbers were normalized by converting to cell carbon (Strathmann 1967). Mean cell volumes used for calculating cell carbon were determined by measuring the size of 30 to 40 cells of each identified species. Rare and unidentified species were grouped in several size classes and their carbon content calculated from average cel]. volumes assigned to each size class. A value of $13.5 \mathrm{pg} \mathrm{C} \mathrm{Cell}^{-1}$ was used for Phaeocystis (Rousseau et al. 1990). Since phytoplankton cell carbon in this study serves merely as a measure for cellular biomass, extra-cellular organic compounds such as the mucus matrix of Phaeocystis colonies were not included

The phytoplankton cellular carbon content associated with aggregates $\left(\mathrm{C}_{\mathrm{agq}}\right)$ was calculated according to the equation

$$
\mathrm{C}_{\mathrm{dgg}}=\mathrm{C}_{\text {bulk }}-\mathrm{C}_{\text {sw }}
$$

where $\mathrm{C}_{\text {bulk }}$ is the cellular carbon content of the bulk water samples (including aggregates); $\mathrm{C}_{\text {sw }}$ is the cellular carbon content of the aggregate-free surrounding water. The amount of Phaeocystis cell carbon associated with aggregates $\left(C_{\text {Phae }}\right)$ was estimated from 
the total amount of aggregated cell carbon $\left(\mathrm{C}_{\text {agg }}\right)$ according to

$$
\mathrm{C}_{\text {Phide }}=\mathrm{C}_{\text {agg }} \times \% \mathrm{C}_{\text {phae }}
$$

where $\% C_{\text {phae }}$ is the mean contribution of Phaeocystis sp., determined from 3 to 6 aggregates per station and depth, to the algal cell carbon content of these aggregates. The standard deviation of $\% \mathrm{C}_{\text {Phae }}$ ranged between 12.3 and $47.8 \%$ of its mean.

Since large aggregates may not have been representatively collected in the $250 \mathrm{ml}$ bulk water samples analysed for phytoplankton cell concentration, $\mathrm{C}_{\text {bulk }}$ may underestimate the total carbon content in the bulk water. Accordingly, $\mathrm{C}_{\text {agg }}$ and $\mathrm{C}_{\text {phae }}$ may represent underestimates.

\section{RESULTS}

In 1989, Phaeocystis cf. globosa contributed significantly to the phytoplankton biomass during the spring bloom in the German Bight, while in 1991 it represented the dominant phytoplankton species (Fig. 2). At the start of the field work in both years, phytoplankton biomass had already settled out of the upper water column and accumulated in the bottom layer (see chl a profiles in Figs. 3A \& 4A). Extremely high biomass concentrations of Phaeocystis were found in the bottom layer at Stn 3 in 1989 and at all stations sampled in 1991 (Figs. 3B \& 4B).
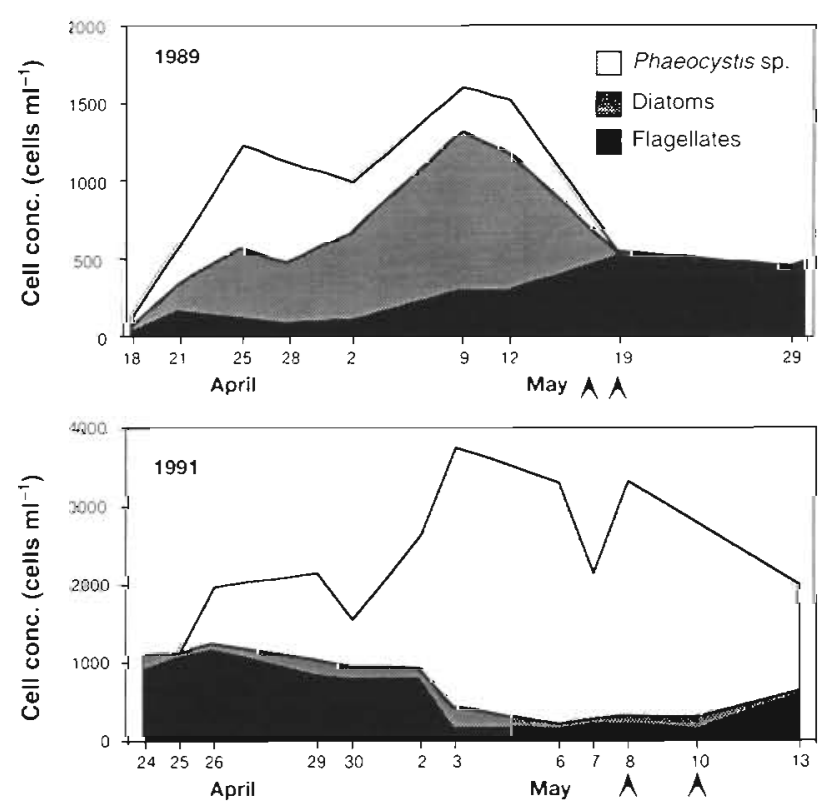

Fig. 2. Phytoplankton cell concentrations of 3 algal groups in the surface water during the spring blooms in 1989 and 1991 Arrows indicate dates of aggregate sampling
Maximum concentrations of Phaeocystis biomass in the surface layer measured prior to the investigation in 1991 were around $35 \mathrm{mg} \mathrm{C} \mathrm{m}^{-3}$ (May 3 to 8). Assuming an even distribution throughout the $16 \mathrm{~m}$ water column results in a total Phaeocystis biomass of $560 \mathrm{mg} \mathrm{C} \mathrm{m}^{-2}$ This is in the same range as the biomass which accumulated in the bottom 2 to $3 \mathrm{~m}$ of the water column at the 3 stations (Fig. 4B), indicating that the loss of Phaeocystis biomass from the upper layers due to grazing and cell lysis was of minor importance.

At the end of both blooms, marine snow aggregates were present throughout the water column. Considerable differences between the 2 years were observed with respect to aggregate size and distribution with depth. In 1989, median aggregate sizes ranged between 0.2 and $1.0 \mathrm{~cm}$ in longest dimension, decreasing steadily with depth (Fig. 3C). In 1991, median sizes varied between 0.4 and $4.9 \mathrm{~cm}$, with smallest sizes being recorded close to the surface and in the bottom layer (Fig. 4C).

The degree of aggregation of Phaeocystis biomass differed significantly between the 2 years investigated. In 1989, while being among the dominating phytoplankton throughout the water column and contributing up to $80 \%$ to the total phytoplankton cell carbon, the relative contribution of Phaeocystis sp. in aggregates was $<2 \%$ at all depths and stations (Fig. 3B). In 1991, on the other hand. Phaeocystis dominated both the total and aggregated phytoplankton biomass, contributing $>60 \%$ to the cell carbon content in aggregates at all depths and stations (Fig. 4B). While in the bottom layer the relative contribution of Phaeocystis cell carbon was similar in the surrounding water and in aggregates, Phaeocystis was enriched in aggregates by a factor of 2 to 3 with respect to the surrounding water at $5 \mathrm{~m}$ water depth, the layer of maximum aggregate size. The enrichment tended to be positively correlated with aggregate size, i.e. the larger the aggregates, the greater the enrichment of Phaeocystis biomass relative to the surrounding water.

A difference in Phaeocystis aggregation between the 2 years is also apparent when comparing aggregated and freely-suspended biomass as calculated from Eqs. 1 \& 2 (Fig. 5). Only a minor fraction of Phaeocystis cell carbon was incorporated in aggregates in 1989 , with no significant differences being found between the surface and bottom layer. In 1991, however, over half of the Phaeocystis cell carbon was associated with aggregates at 5 and $10 \mathrm{~m}$ depth, while in the bottom layer only a small fraction of the Phaeocystis biomass was concentrated in aggregates. These data are also supported by visual observations made during SCUBA dives. In the upper layer, characterized by an abundance of large aggregates, colonies of Phaeocystis were seen attached to aggregates (Fig. 6). On the other 
A

$\square$ Density $\left(\sigma_{t}\right)$
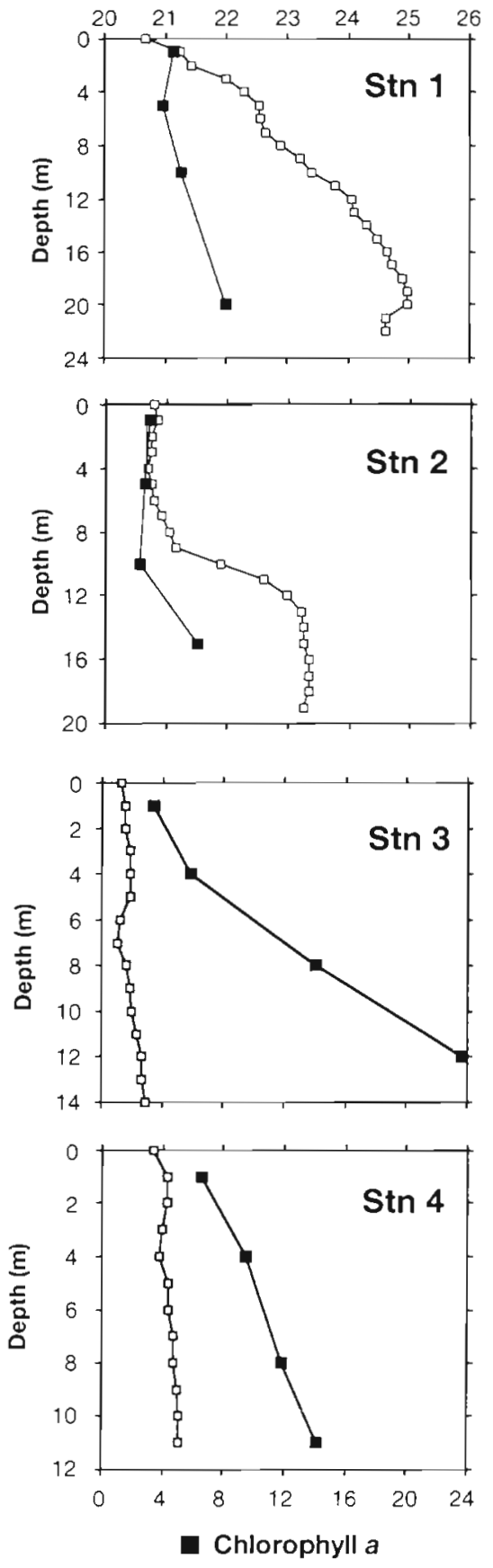

$\left(\mathrm{mg} \mathrm{m}^{-3}\right)$
B

Phytoplankton Carbon

$\left(\mathrm{mg} \mathrm{m}^{-3}\right.$ )
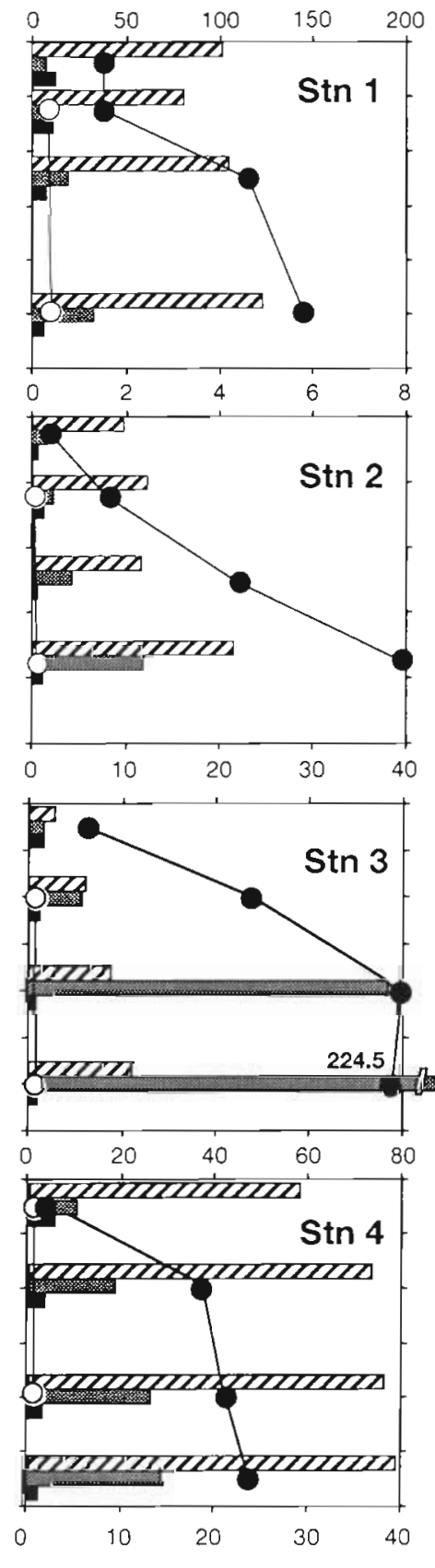

Phaeocystis sp. $\stackrel{0-}{\rightarrow}$

(\% of total phytoplankton carbon)

Surrounding Water

Marine Snow Aggregates
C

Marine Snow Size

(cm longest dimension)
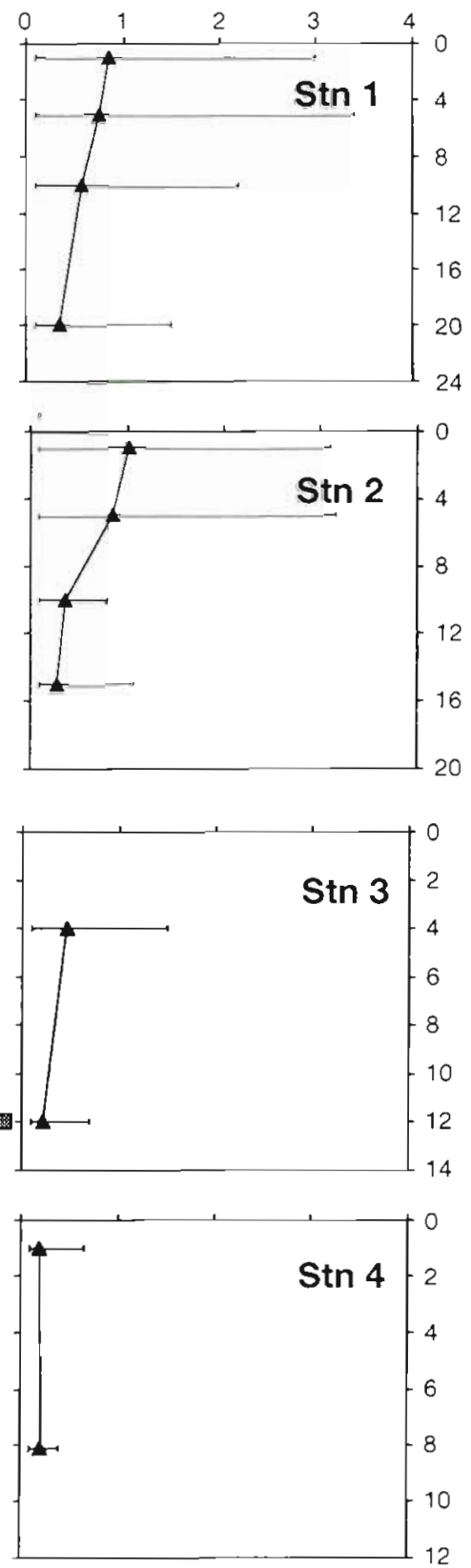

7 Diatoms

Phaeocystis sp.

Other Microphytoplankton

Fig. 3. Data for Stns 1 to 4 (May 17 and 19, 1989): (A) depth profules of seawater density and chlorophyll $a_{i}$ (B) phytoplankton carbon concentrations of 3 groups (bars) and Phaeocystis biomass in the surrounding water (O) and in aggregates (O) as percent of total phytoplankton biomass; (C) marine snow size ( $\wedge$ : median values; horizontal bars: size ranges). Note differences in lower scales in (B) 
A

Density $\left(\sigma_{t}\right)$
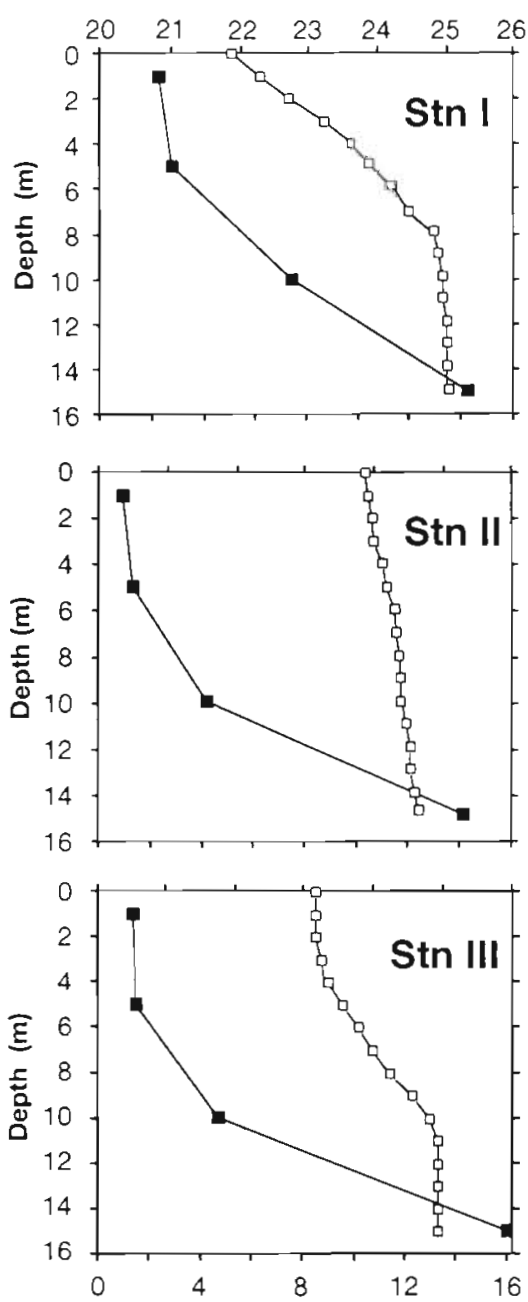

Chlorophyll a

(mg m${ }^{-3}$ )
B

Phytoplankton Carbon $\left(\mathrm{mg} \mathrm{m}^{-3}\right)$
C

Marine Snow Size

(cm in longest dimension)
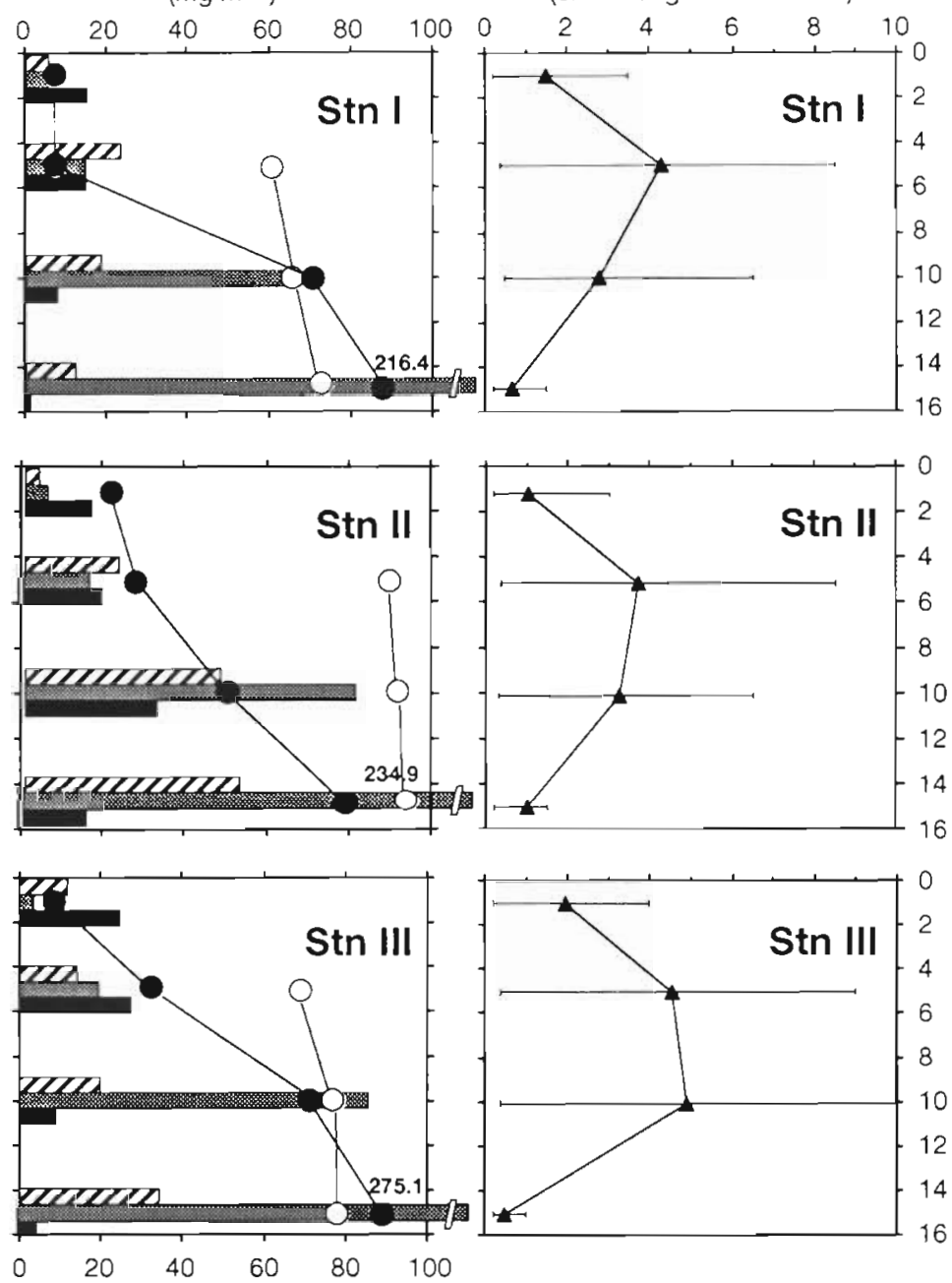

Phaeocystis sp. $\stackrel{-}{-}-$

(\% of total phytoplankton carbon)

Surrounding Water

Marine Snow Aggregates

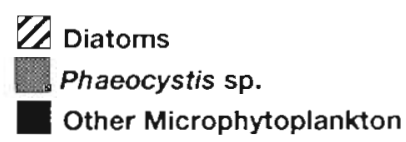

Fig. 4. Data for Stns I to III (May 8 and 10, 1991) plotted as in Fig. 3

hand, most of the Phaeocystis material that had settled to the bottom layer was in the form of individual, freely-suspended colonies.

In situ observation and microscopic examination revealed that colonies of Phaeocystis associated with aggregates were generally attached to the outside of the aggregate rather than being incorporated in the matrix. The aggregate matrix consisted mainly of densely-packed diatoms and detritus. No correlation was found between colony size and shape and the degree of aggregation. Both spherical and elongated (presumedly senescent) colonies were observed in free suspension and attached to aggregates. No detectable change with depth was found in the ratio of spherical to elongated colonies.

A comparison of the contribution of various algal groups to the phytoplankton cell carbon in aggregates with their relative contribution to the cell carbon in the surrounding water reveals differences in their aggregation potentials (Table 1). Phaeocystis, which largely remained unaggregated in 1989, contributed significantly to phytoplankton cell carbon in aggregates in 
1989
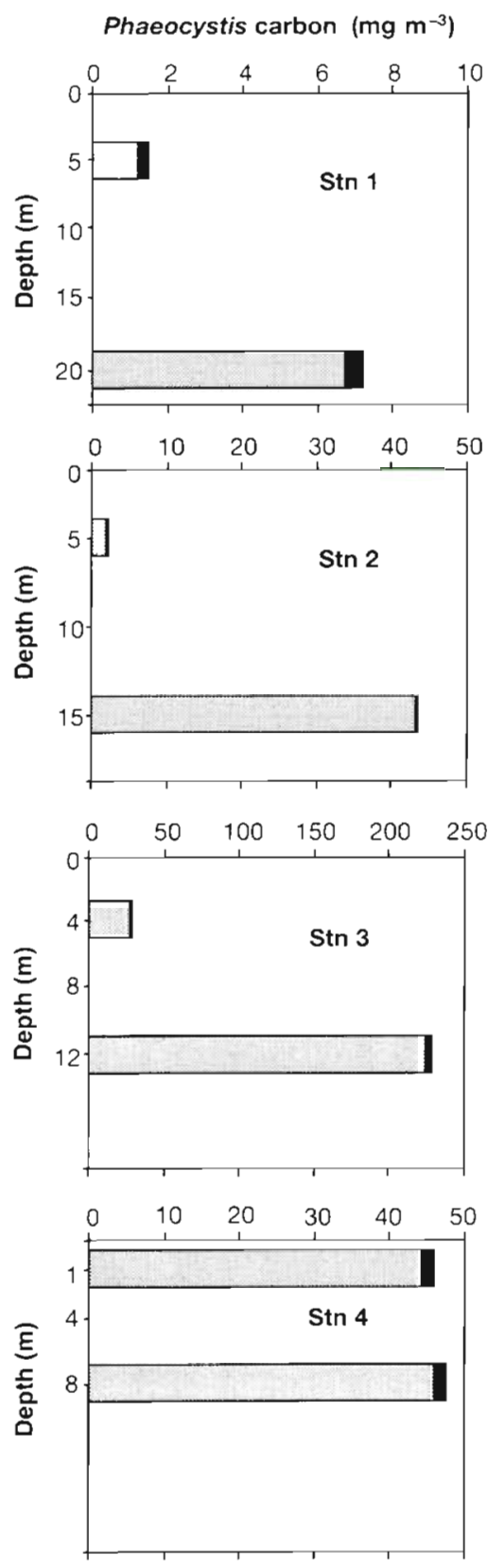

1991

Phaeocystis carbon ( $\mathrm{mg} \mathrm{m}^{-3}$ )
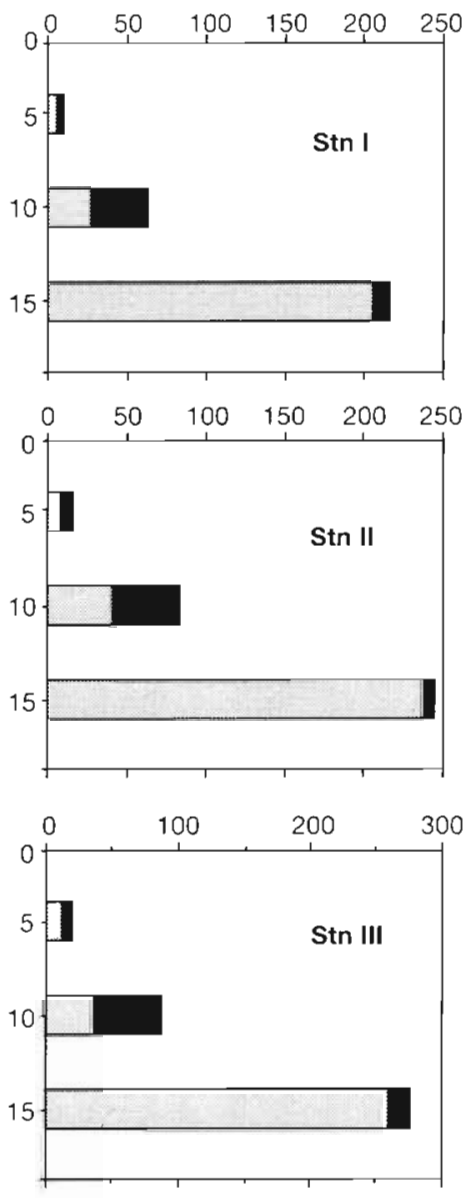

freely suspended

associated with aggregates

Fig. 5. Phaeocystis biomass in free suspension and associated with aggregates. Note differences in scales

siderably higher in the surrounding water than in aggregates. $N$. miliaris, a species known to produce mucous nets when feeding by so-called 'mucoidfiltration' (Uhlig 1982), was found exclusively in association with aggregates. Similarly, fecal pellets were always abundant in aggregates but were not found freely suspended in the surrounding water.

\section{DISCUSSION}

The data provide seemingly contradictory evidence with regard to the aggregation behaviour of Phaeocystis during the decline of blooms. The scenario emerging from the 1989 investigation reveals marine snow aggregates which are nearly devoid of Phaeocystis cells and most of the Phaeocystis biomass being in the form of freely suspended colonies. In 1991, on the other hand, more than half of the Phaeocystis biomass in the upper water column was associated with aggregates, generally in the form of large colonies being attached to aggregates.

Considering that Phaeocystis colonies in aggregates were generally only loosely attached to the aggregate matrix, a possible explanation for the apparent discrepancy is suggested by the difference in aggregate size between the 2 blooms. During an 18 mo investigation in 1989/1990 in the same area, Riebesell (1992) found a correlation between aggregate size and windinduced turbulent mixing of the water column. Based on this correlation, the observed difference in aggregate size between 1989 and 1991 can be related to a difference in the level of turbulence

1991. At this time Phaeocystis biomass was enriched in aggregates relative to the surrounding water by a factor of 1.5 to 2 . In comparison, the diatoms Chaetoceros socialis, Coscinodiscus sp., Asterionella glacialis, and Odontella sinensis were highly enriched in aggregates, with enrichment factors ranging for the most part between 2 and 15, indicating a higher aggregation potential of these species relative to Phaeocystis. A low aggregation potential can be inferred for dinoflagellates whose relative contribution, with the exception of the heterotrophic dinoflagellate Noctiluca miliaris, was con- between the 2 years. Thus, while attachment of large particles such as Phaeocystis colonies to the comparatively small aggregates (generally $<1 \mathrm{~cm}$ ) forming during the decline of the 1989 bloom may have been prevented by turbulent shear, conditions during the 1991 bloom were sufficiently calm to allow formation of large (up to $10 \mathrm{~cm}$ ) aggregates and attachment of Phaeocystis colonies to them.

Variability in both aggregate size and the proportion of Phaeocystis biomass in aggregates with depth as observed during the 1991 investigation (Figs. 4 \& 5) may 


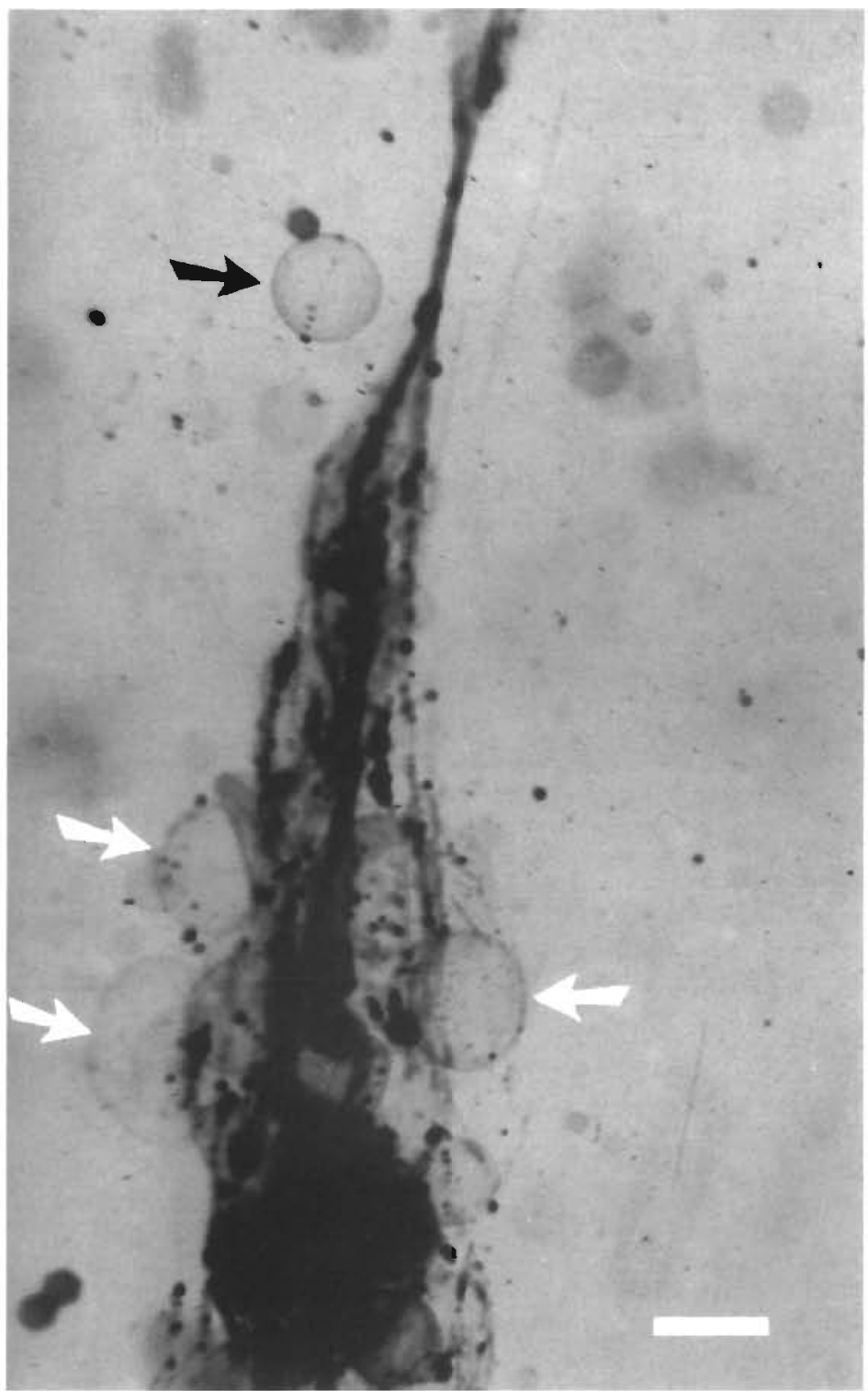

Fig. 6. In situ photograph of a marine snow aggregate with colonies of Phaeocystis attached to it (white arrows) and freely-suspended (black arrow): Stn III, $5 \mathrm{~m}$ water depth. Scale bar $=5 \mathrm{~mm}$. Phaeocystis-rich aggregates of this kind were abundant in the upper layer during the 1991 bloom

be related to differences in the level of turbulent shear between different layers in the water column. While wind-induced mixing could account for small aggregate sizes close to the surface, tidal current-related turbulent shear decreased aggregate size and the proportion of aggregated Phaeocystis biomass in the bottom layer. Tidal currents may also be responsible for keeping Phaeocystis in suspension in the bottom layer, as observed at Stn 3 in 1989 and at all stations sampled in 1991.

Although intact colonies became attached to marine snow aggregates under low shear conditions, Phaeo- cystis appeared to be of little significance for initiating aggregate formation. This is in contrast to the diatom species present during the time of investigation, which were generally incorporated within the aggregate matrix and were significantly enriched in aggregates in comparison to the surrounding water (Table 1). While diatoms were found to be a predominant component of marine snow in many studies (see Alldredge \& Silver 1988), incorporation of colonial Phaeocystis in marine snow aggregates was observed only for Phaeocystis released from Antarctic sea ice during spring melting (Riebesell et al. 1991). However, unlike pelagic microalgae which remain freely suspended by exhibiting low values of cell stickiness during favourable growth (Kiørboe et al. 1990), many ice algae produce extensive extracellular polysaccharide mucilages which permit attachment to the ice substrate (McConville 1985). Differences in stickiness between pelagic and ice-inhabiting Phaeocystis may be species- and/or habitatrelated.

Large marine snow flocs such as the Phaeocystis-rich aggregates formed during the 1991 bloom have been observed to be slowly sinking, neutrally buyoant, or rising, resulting in their prolonged residence in the surface layer (Riebesell 1992). Thus, colony aggregation does not necessarily imply rapid sedimentation of Phaeocystis biomass. On the other hand, sinking rates of Phaeocystis colonies are sufficiently high (around $7 \mathrm{~m} \mathrm{~d}^{-1}$; van Boekel et al. 1992) to permit sedimentation without invoking aggregation. In fact, independent of whether colonies became attached to aggregates or remained freely suspended, sedimentation was the dominant loss factor of Phaeocystis biomass from the surface layer during this study. Roughly the same amount of biomass which accumulated in the water column during the build-up of the Phaeocystis bloom was concentrated in the bottom layer after its sedimentation (see above). Hence, loss of Phaeocystis biomass in the upper mixed layer due to grazing or cell lysis was insignificant.

A high aggregation potential of colonial Phaeocystis due to increasing surface stickiness of senescent colonies during the decline of the bloom, as suggested by Wassmann et al. (1990), was not observed during this study. Aging of nutrient-limited Phaeocystis globosa colonies in laboratory experiments with pure cultures resulted in disintegration rather than aggregation of the colonies (Riebesell \& Griebe 
Table 1. Contribution of selected species/groups to the phytoplankton cell carbon in water samples free of aggregates (SW: surrounding water) and in aggregates as percent of total. Data represent mean values of samples collected throughout the water column; $n=$ numbers of samples

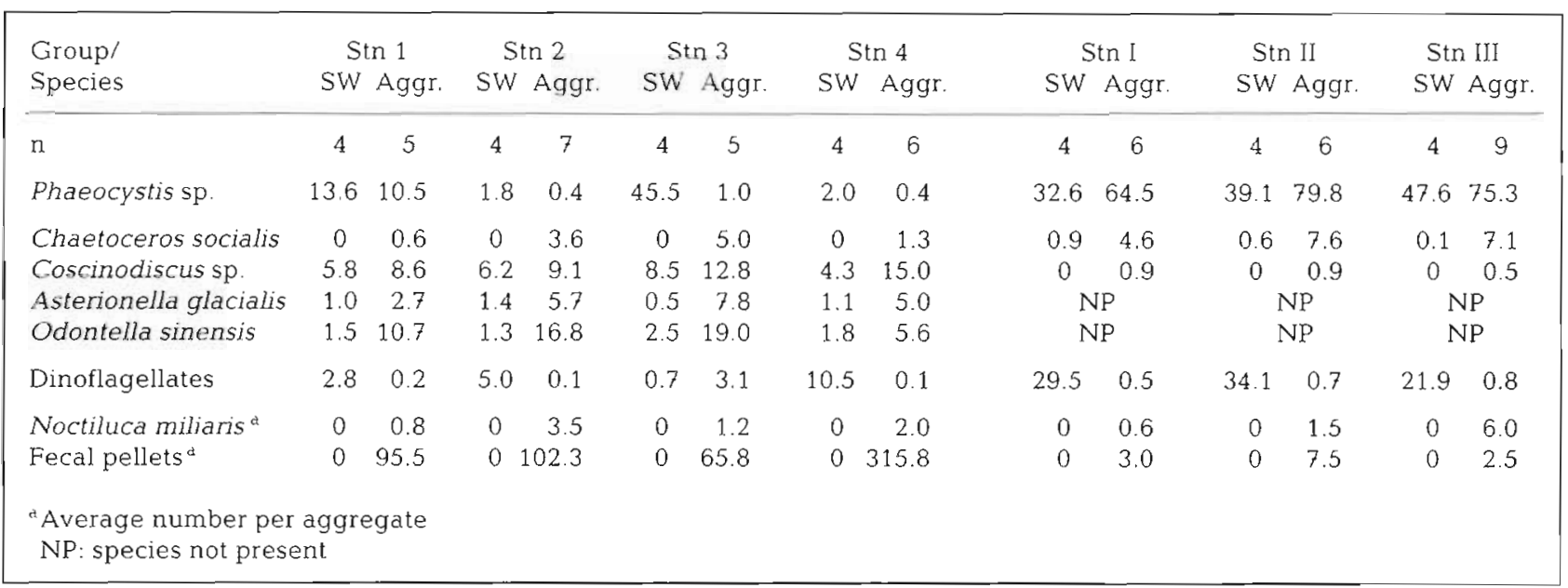

unpubl.). Colony disintegration and cell-lysis were found to be the main loss factor during the decline of a Phaeocystis bloom in the Marsdiep area of the North Sea with sedimentation of Phaeocystis being insignificant (van Boekel et al. 1992). As this is an area characterized by high current velocities, sedimenting material is subjected to continuous resuspension resulting in little net sedimentation (Jenness \& Duineveld 1985). Thus, with resuspension having prevented sedimentation of Phaeocystis during the bloom decline, Phaeocystis colonies suspended in a nutrient-depleted water column may experience rapid disintegration.

As was observed during this study, disintegration can be retarded when the colonies settle into a nutrient-replete bottom layer, where on account of the shallow depth, phytoplankton experience sufficient light to continue slow growth. In deeper water, on the other hand, disintegration may become significant for colonies which have settled out of the euphotic zone. A rapid decrease in the vertical flux of Phaeocystis biomass below the euphotic zone was in fact observed by Lutter et al. (1989) and Wassmann et al. (1990), suggesting that colony disintegration, among other loss factors, may prevent deep flux of Phaeocystis biomass.

Prolonged suspension in the bottom layer of shallow coastal waters such as those of the southern North Sea would enhance the probability of Phaeocystis biomass becoming transported to shore, where it may cause the formation of large amounts of foam on the beaches. This has been observed along the North Sea coast after intense Phaeocystis blooms (Lancelot et al. 1987). Differences in aggregation between Phaeocystis and diatoms, as discussed above, could reinforce the role of
Phaeocystis in foam formation. While diatoms tend to be firmly entangled in aggregates and therefore are likely to become incorporated in the sediment after settling to the bottom, loosely attached colonies of Phaeocystis can easily be detached from settling aggregates when subjected to tidal current-induced shear in the bottom layer. This difference in aggregation behaviour may be one of the reasons why foam formation is correlated to blooms of Phaeocystis rather than of diatoms.

Acknowledgements. The field investigation of this work was carried out at the Biologische Anstalt Helgoland (BAH). Thanks go to the captains and crews of RV 'Diker', 'Aade', and 'Uthörn' and to U. Schilling and the BAH diving crew for technical support in the field. Data on surface water phytoplankton cell. concentrations for 1991 were kindly provided by E. Hagmeier and K. Treutner. I am grateful to If Candia and R. Jakobi for microscopic analyses, to U. Passow for helpful comments, and to $M$. Botros for critical reading of and improvements to the manuscript.

\section{LITERATURE CITED}

Alldredge, A. L., Silver, M. W. (1988). Charactenstıcs, dynamics and significance of manne snow. Prog. Oceanogr 20: $41-82$

Baumann, M. (1990). Untersuchungen zur Primärproduktion und Verteilung des Phytoplanktons der Grönlandsee mit Kulturexperimenten zum Einfluß des Lichtes und der Temperatur auf Wachstum und Photosynthese arktischer Diatomeen. Ph.D. thesis, Univ. of Aachen

Bodungen, B. v., Smetacek, V., Tilzer, M. M., Zeitzschel, B. (1986). Primary production and sedimentation during spring in the Antarctic Peninsula region. Deep Sea Res. 33: 177-194

Buck, K. R., Garrison, D. L. (1983). Protists from the ice-edge region in the Weddell Sea. Deep Sea Res. 30: 1261-1277 
Eilertsen, H. C., Schei, B., Taasen, J. (1981). Investıgation of the plankton community of Balsfjorden, northern Norway. Sarsia 66: 129-141

El-Sayed, S. Z., Biggs, D. C., Holm-Hansen, O. (1983). Phytoplankton standing crop, primary productivity and nearsurface nitrogenous nutrient fields in the Ross Sea, Antarctica. Deep Sea Res. 30: 871-886

Hansen, F. C., van Boekel, W. H. M. (1991). Grazing pressure of the calanoid copepod Temora longicornis on a Phaeocystis dominated spring bloom in Dutch coastal waters. Mar. Ecol. Prog. Ser. 78: 123-129

Jenness, M. I., Duineveld, G. C. A. (1985). Effects of tidal currents on chlorophyll a content of sandy sediments in the southern North Sea. Mar. Ecol. Prog. Ser. 21: 283-287

Kiørboe, T., Andersen, K. P., Dam, H. G. (1990). Coagulation efficiency and aggregate formation in marine phytoplankton. Mar. Biol. 107: 235-245

Lancelot, C., Billen, G., Sournia, A., Weisse, T., Colijn, F., Veldhuis, M. J. W. Davies, A., Wassmann, P. (1987). Phaeocystis blooms and nutrient enrichment in the continental coastal zones of the North Sea. Ambio 16: 38-46

Lutter, S., Taasen, J. P., Hopkins, C. C. E., Smetacek, V. (1989). Phytoplankton dynamics and sedimentation processes during spring and summer in Balsfjord, northern Norway. Polar Biol. 10: 113-124

McConville, M. J. (1985). Chemical composition and biochemistry of sea ice microalgae. In: Horner, R. A. (ed.) Sea ice biota. CRC Press, Boca Raton, p. 105-129

Parsons, T. R., Maita, Y., Lalli, C. M. (1984). A manual of chemical and biological methods for seawater analysis. Pergamon Press, New York

Radach, G., Berg, J., Hagmeier, E. (1990). Long-term changes of the annual cycles of meteorological, hydrographic, nutrient and phytoplankton time series at Helgoland and at LV ELBE 1 in the German Bight. Cont. Shelf Res. 10: $305-328$

Riebesell, U. (1991a). Particle aggregation during a diatom bloom. I. Physical aspects. Mar. Ecol. Prog. Ser. 69: $273-280$

Riebesell, U. (1991b). Particle aggregation during a diatom bloom. II. Biological aspects. Mar. Ecol. Prog. Ser. 69: $281-291$

Riebesell, U. (1992). The formation of large marine snow and its sustained residence in surface waters. Limnol. Oceanogr. 37: 63-76

Riebesell, U., Schloss, I., Smetacek, V. (1991). Aggregation of algae released from melting sea ice: implications for seeding and sedimentation. Polar Biol. 11: 239-248

Rousseau, V., Mathot, S., Lancelot, C. (1990). Calculating carbon biomass of Phaeocystis sp. from microscopic observations. Mar. Biol. 107: 305-314

This article was submitted to the editor
Rousseau, V., Vaulot, D., Lenz. J., Baumann, M. (in press). The Phacocystis life cycle: evidence and hypotheses. In: Wassmann, P., Lancelot, C. (eds.) The ecology of Phaeocystis: present perspectives and future research. J. mar. Syst

Schnack, S. B., Smetacek, V., von Bodungen, B., Stegmann, P. (1985). Utilization of phytoplankton by copepods in Antarctic waters during spring. In: Gray, J. S., Christıansen, M. E. (eds.) Marne biology in polar regions and effects of stress on marine organisms. Wiley, London, p. $65-81$

Smith, W. O., Codispoti, L. A., Nelson, D. M., Manley, T., Buskey, E. J., Niebauer, H. J., Cota, G. F. (1991). Importance of Phaeocystis blooms in the high-latitude ocean carbon cycle. Nature 352: $514-516$

SooHoo, B. J., Palmisano, A. C., Kottmeier, S. T., Lizotte, M. P., SooHoo, S. L., Sullivan, C. W. (1987). Spectral light absorption and quantum yield of photosynthesis in sea ice microalgae and a bloom of Phaeocystis pouchetii from McMurdow Sound, Antarctica. Mar. Ecol. Prog. Ser. 39: $175-189$

Strathmann, R. R. (1967). Estimating the organic carbon content of phytoplankton from cell volume or plasma volume Limnol. Oceanogr. 12: 411-418

Tande, K. S., Bamstedt, U. (1987). On the trophic fate of Phaeocystis pouchetii. I. Copepod feeding rates on solitary cells and colonies of $P$. pouchetii. Sarsia 72: 313-320

Uhlig, G. (1982). In: Paranajape, A., Gold, K. Cultivation of marine pelagic protozoa. Annls lnst. océanogr. Paris 58 : $143-150$

van Boekel, W. H. M., Hansen, F. C., Riegman, R., Bak, R. P. M. (1992). Lysis-induced decline of a Phaeocystis spring bloom and coupling with the microbial foodweb. Mar. Ecol. Prog. Ser. 81: 269-276

Veldhuis, M. J. W., Colijn, F., Venekamp, L. A. H. (1986). The spring bloom of Phaeocystis pouchetii (Haptophyceae) in Dutch coastal waters. Neth. J. Sea Res. 20: 37-48

Verity, P. G., Smayda, T. J. (1989). Nutritional value of Phaeocystis pouchetii (Prymnesiophyceae) and other phytoplankton for Acartia spp. (Copepoda): ingestion, egg production, and growth of nauplii. Mar. Biol. 100: 161-171

Wassmann, P. (in press). Significance of sedimentation for the termination of Phaeocystis blooms. In: Wassmann, P., Lancelot, C. (eds.) The ecology of Phaeocystis: present perspectives and future research. J. mar. Syst.

Wassmann, P., Vernet, M., Mitchell, B. G. (1990). Mass sedimentation of Phaeocystis pouchetii in the Barents Sea. Mar. Ecol. Prog. Ser. 66: 183-195

Weisse, T., Scheffel-Möser, U. (1990). Growth and grazing loss rates in single-celled Phaeocystis sp. (Prymnesiophyceae). Mar. Biol. 106: 153-158

Manuscript first received: January 19, 1993

Revised version accepted: April 19, 1993 